\title{
РЕЦЕНЗIÏ
}

DOI: https://dx.doi.org /10.18524/2312-6809.2018.27.146427

\section{ЩЕ ОДИН КРОК В ОСМИСЛЕННІ ЖАНРОВОЇ ПРИРОДИ «ПОЕЗІї В ПРОЗІ»}

Ірина Нечиталюк, канд. філол. наук, доц.

Одеський національний університет імені I. I. Мечникова

niv2010@ukr.net

Рецензія: Гжсегожевська Т. О. Жанр поезії в прозі в украйнській літературі XX cm. Еволюція. Поетика : Монографія. - Кам'янець-Подільський : Кам'янець-Подільський національний університет, 2017. $160 c$.

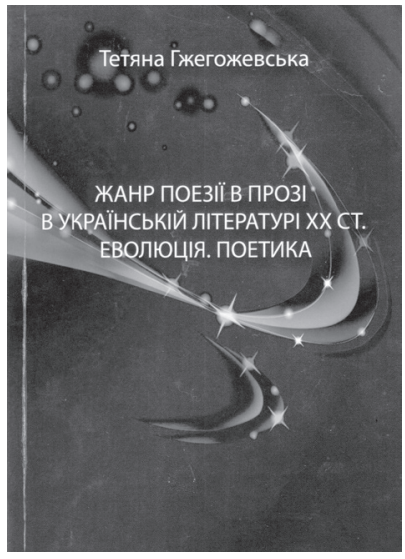

Дослідження цікаве принаймні з двох причин: насамперед тим, що увага зосереджена на системному аналізі творчості численної плеяди українських письменників, починаючи з кінця XIX і по 60-80 роки XX століття, а також і тим, що пропонує цілісний аналіз досі несправедливо обійденого увагою жанру - «поезії у прозі».

В монографії дві художні системи протиставляються одна одній як такі, що органічно доповнюючи одна одну, вивершуть нові змістоорганізуючі можливості як лірики, так і прози.

Перший розділ монографії присвячено висвітленню теоретико-методологічних засад вивчення «поезії у прозі». На особливу увагу заслуговує аналіз генези та еволюції поезії у прозу та виокремлення ознак жанру. На думку дослідниці, «поезія у прозі - це особливий жанр, якому властиві поєднання ліризму з прозовим викладом (ліро-епічна природа), настроєвість, фрагментарність, суб'єктивність, психологізм, поетичне звучання, сфокусованість на переживаннях, почуттях. Лінійна організація мовного ма-

(C) Нечиталюк I., 2018 
теріалу в таких творах зумовлює смислову, інформативну та трохеїчну варіативність тексту, який, з одного боку, може бути абстрактним, або конкретним» [36].

Для опрацювання доволі великої кількості матеріалу Т. Гжегожевська, цілком логічно, обрала хронологічний порядок при організації структури монографії. Так, другий розділ присвячено аналізу жанрових модифікацій «поезії у прозі» першої половини XX століття. Попри значну кількість постатей (О. Кобилянська, Леся Українка, М. Яцків, Г. Хоткевич, Б. Лепкий), обрану авторкою для дослідження викликає певне здивування відсутність таких майстрів художнього слова, як В. Стефаник та М. Коцюбинський, а між тим означений жанр не тільки був виразно заявлений у творчості останніх, а й, безперечно, належить до кращих зразків «поезій у прозі» зазначеного періоду.

Третій розділ: «Розвиток жанру поезії в прозі у творчості українських письменників 60-80 років XX століття» присвячено розгляду особливостей жанру у творчості Нью-Йоркської групи (Ю. Тарнавський, Р. Бабовал), що виводить дослідження з географії материкової України і залучає діаспорну культуру; шістдесятників (І. Драч, С. Гуцало); Київської школи (В. Голобородько, М. Воробйов). В окремому підрозділі досліджується творчість В. Затуливітра, що, на мою думку, виглядає не цілком вмотивованим.

Підсумовуючи аналіз шляхів розвитку «поезій у прозі» в українській літературі 1960-1980-х років, Т. Гжегожовська підкреслює, що «цей жанр зазнає змін. Тематологічний зріз дає уявлення про спектр порушених питань - загальнолюдських, вічних і часткових, мінливих, - що постають у різних авторів, які скористалися жанровою моделлю. Це питання швидкоплинності часу, сенсу буття людини і покликання творчої особистості, трагічного дитинства на тлі воєнних подій, нерозривного зв'язку з рідною землею та ії минулим» [131].

Принциповою i, на мою думку, переконливою є позиція автора рецензованої монографії щодо того, що «поезія в прозі стала одним із засобів подолання стильових канонів прози. Суб'єктивність, авторські рефлексії, що переростають у художній автобіографізм, превалювання вираження над зображенням, перехід від зовнішньо-подієвого до внутрішньо-психологічного сюжету і визначили особливість способу сприйняття та відтворення світу, які дають авторам поезії в прозі на малій площі художнього твору передати універсальність світу і поліфонізм його звучання» [139]. 
Висновки монографії впорядковано таким чином, що не лише підсумовують ключові моменти роботи у відповідності до поставлених завдань, а й чітко доводять, що жанр «поезії у прозі» є складним синтетичним утворенням, у межах якого відбуваються активні процеси дифузії жанрової системи, зумовлені проникненням ліричного струменя у прозову канву тесту.

Заслуговує на повагу список опрацьованих джерел (біля 300), що, безперечно, вказує на широку обізнаність дослідниці із науковим контекстом з зазначеної проблематики, та надає ваги висновкам, до яких дійшла Т. Гжегожевська.

Монографія Т. Гжегожевської читається легко і викликає цікавість, оскільки написана, з одного боку, лаконічним науковим стилем, з іншого, не переобтяжена складною термінологією та химерними синтаксичними конструкціями. Запропонована авторська модель розвитку жанру поезії у прозі XX столітті - одного з найважливіших етапів літературного процесу - стала гідним внеском у сучасне літературознавство.

Стаття надійшла до редакції 7 липня 2018 р. 